4

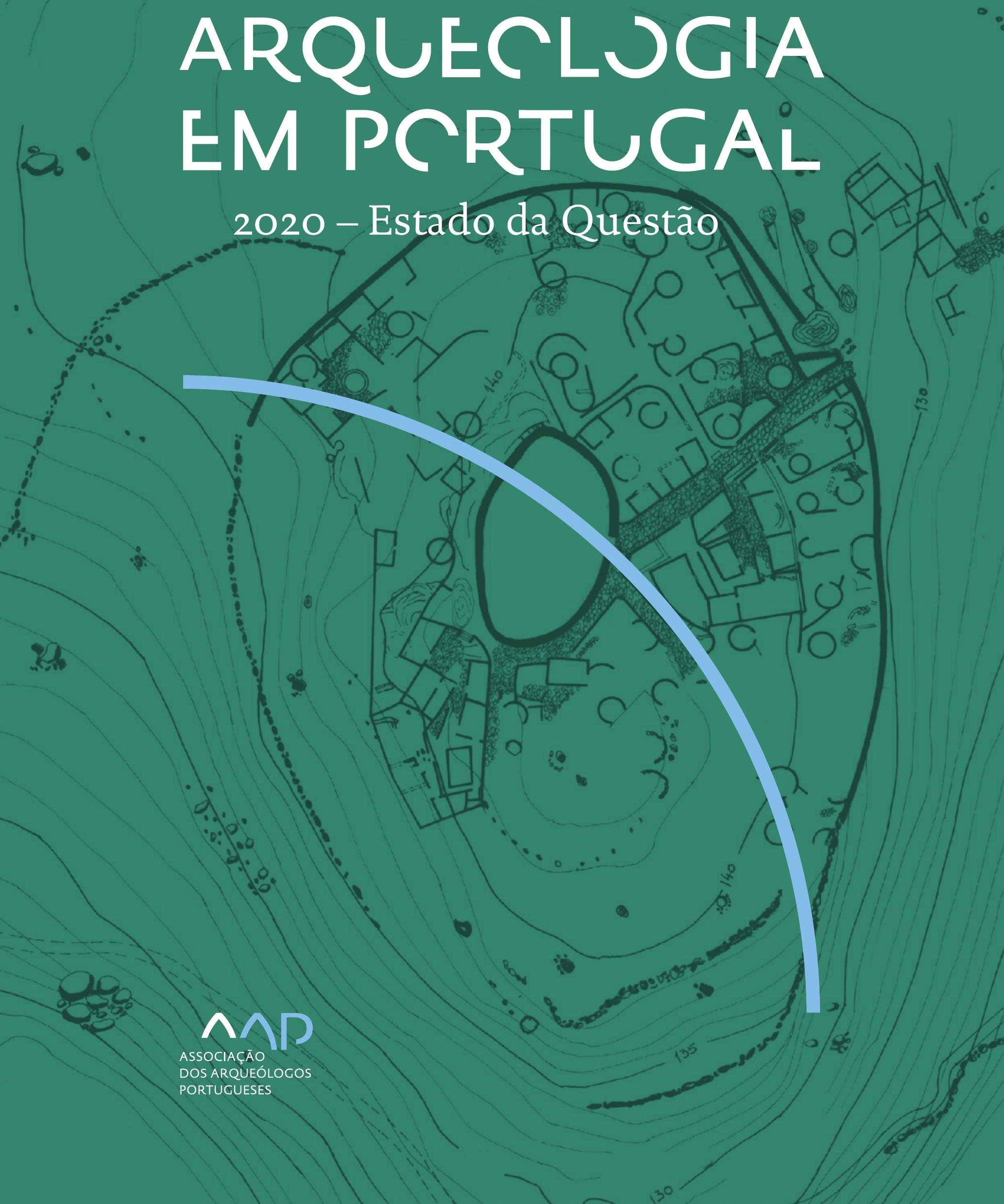


Coordenação editorial: José Morais Arnaud, César Neves e Andrea Martins Design gráfico: Flatland Design

AAP - ISBN: 978-972-9451-89-8

CITCEM - ISBN: 978-989-8970-25-1

Associação dos Arqueólogos Portugueses e CITCEM

Lisboa, 2020

O conteúdo dos artigos é da inteira responsabilidade dos autores. Sendo assim a Associação dos Arqueólogos Portugueses declina qualquer responsabilidade por eventuais equívocos ou questões de ordem ética e legal.

Desenho de capa:

Planta do castro de Monte Mozinho (Museu Municipal de Penafiel).

\section{$\hat{\wedge} \mathrm{P}$}

DOS ARQUEÓLOGOS PORTUGUESES

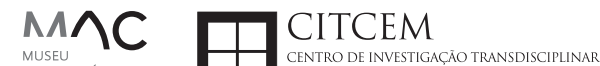
MUSEU
ARQUELLÓGICO
DO CARMO
U.PORTO

FLUP FACULDADE DE LETRAS
UNIVERSIDADE DO PORTO

Apoio

EC para a Ciência 


\section{Índice}

15 Prefácio

José Morais Arnaud

\section{Historiografia e Teoria}

17 Território, comunidade, memória e emoção: a contribuição da história da arqueologia (algumas primeiras e breves reflexões)

Ana Cristina Martins

25 Como descolonizar a arqueologia portuguesa?

Rui Gomes Coelho

41 Arqueologia e Modernidade: uma revisitação pessoal e breve de alguns aspetos da obra homónima de Julian Thomas de 2004

Vítor Oliveira Jorge

57 Dados para a História das Mulheres na Arqueologia portuguesa, dos finais do século XIX aos inícios do século XX: números, nomes e tabelas

Filipa Dimas / Mariana Diniz

73 Retractos da arqueologia portuguesa na imprensa: (in)visibilidades no feminino

Catarina Costeira / Elsa Luís

85 Arqueologia e Arqueólogos no Norte de Portugal Jacinta Bugalhão

101 Vieira Guimarães (1864-1939) e a arqueologia em Tomar: uma abordagem sobre o território e as gentes

João Amendoeira Peixoto / Ana Cristina Martins

115 Os memoráveis? A arqueologia algarvia na imprensa nacional e regional na presente centúria (2001-2019): características, visões do(s) passado(s) e a arqueologia

enquanto marca

Frederico Agosto / João Silva

129 A Evolução da Arqueologia Urbana e a Valorização Patrimonial no Barlavento Algarvio: Os casos de Portimão e Silves

Artur Mateus / Diogo Varandas / Rafael Boavida

\section{Gestão, Valorização e Salvaguarda do Património}

145 O Caderno Reivindicativo e as condições de trabalho em Arqueologia Miguel Rocha / Liliana Matias Carvalho / Regis Barbosa / Mauro Correia / Sara Simões / Jacinta Bugalhão / Sara Brito / Liliana Veríssimo Carvalho / Richard Peace / Pedro Peça / Cézer Santos

155 Os Estudos de Impacte Patrimonial como elemento para uma estratégia sustentável de minimização de impactes no âmbito de reconversões agrícolas Tiago do Pereiro

165 Salvaguarda de Património arqueológico em operações florestais: gestão e sensibilização Filipa Bragança / Gertrudes Zambujo / Sandra Lourenço / Belém Paiva / Carlos Banha / Frederico Tatá Regala / Helena Moura / Jacinta Bugalhão / João Marques / José Correia / Pedro Faria / Samuel Melro

179 Os valores do Património: uma investigação sobre os Sítios Pré-históricos de Arte Rupestre do Vale do Rio Côa e de Siega Verde José Paulo Francisco 
189 Conjugando recursos arqueológicos e naturais para potenciar as visitas ao Geoparque Litoral de Viana do Castelo (Noroeste de Portugal)

Hugo A. Sampaio / Ana M.S. Bettencourt / Susana Marinho / Ricardo Carvalhido

203 Áreas de Potencial Arqueológico na Região do Médio Tejo: Modelo Espacial Preditivo Rita Ferreira Anastácio / Ana Filipa Martins / Luiz Oosterbeek

223 Património Arqueológico e Gestão Territorial: O contributo da Arqueologia para a revisão do PDM de Avis

Ana Cristina Ribeiro

237 A coleção arqueológica do extinto Museu Municipal do Porto - Origens, Percursos e Estudos

Sónia Couto

251 Valpaços - uma nova carta arqueológica

Pedro Pereira / Maria de Fátima Casares Machado

263 Arqueologia na Cidade de Peniche

Adriano Constantino / Luís Rendeiro

273 Arqueologia Urbana: a cidade de Lagos como caso de Estudo Cátia Neto

285 Estratégias de promoção do património cultural subaquático nos Açores. O caso da ilha do Faial

José Luís Neto / José Bettencourt / Luís Borges / Pedro Parreira

297 Carta Arqueológica da Cidade Velha: Uma primeira abordagem

Jaylson Monteiro / Nireide Tavares / Sara da Veiga / Claudino Ramos / Edson Brito /

Carlos Carvalho / Francisco Moreira / Adalberto Tavares

311 Antropologia Virtual: novas metodologias para a análise morfológica e funcional Ricardo Miguel Godinho / Célia Gonçalves

\section{Didáctica da Arqueologia}

327 Como os projetos de Arqueologia podem contribuir para uma comunidade culturalmente mais consciente Alexandra Figueiredo / Claúdio Monteiro / Adolfo Silveira / Ricardo Lopes

337 Educação Patrimonial - Um cidadão esclarecido é um cidadão ativo! Ana Paula Almeida

351 A aproximação da Arqueologia à sala de aula: um caso de estudo no $3^{\circ}$ ciclo do Ensino Básico Luís Serrão Gil

363 Arqueologia 3.o - Pensar e comunicar a Arqueologia para um futuro sustentável Mónica Rolo

377 “Conversa de Arqueólogos" - Divulgar a Arqueologia em tempos de Pandemia Diogo Teixeira Dias

389 Escola Profissional de Arqueologia: desafios e oportunidades Susana Nunes / Dulcineia Pinto / Júlia Silva / Ana Mascarenhas

399 Os Museus de Arqueologia e os Jovens: a oferta educativa para o público adolescente Beatriz Correia Barata / Leonor Medeiros

411 O museu universitário como mediador entre a ciência e a sociedade: o exemplo da secção de arqueologia no Museu de História Natural e da Ciência da Universidade do Porto (MHNC-UP)

Rita Gaspar 
421 Museu de Lanifícios: Real Fábrica de Panos. Atividades no âmbito da Arqueologia Beatriz Correia Barata / Rita Salvado

427 Arqueologia Pública e o caso da localidade da Mata (Torres Novas) Cláudia Manso / Ana Rita Ferreira / Cristiana Ferreira / Vanessa Cardoso Antunes

431 Do sítio arqueológico ao museu: um percurso (também) didático Lídia Fernandes

447 Estão todos convidados para a Festa! E para dançar também... O projecto do Serviço Educativo do Museu Arqueológico do Carmo na $5^{\underline{a}}$ Edição da Festa da Arqueologia Rita Pires dos Santos

459 O “Clã de Carenque”, um projeto didático de arqueologia Eduardo Gonzalez Rocha

469 Mediação cultural: peixe que puxa carroça nas Ruínas Romanas de Troia Inês Vaz Pinto / Ana Patrícia Magalhães / Patrícia Brum / Filipa Santos

481 Didática Arqueológica, experiências do Projeto Mértola Vila Museu Maria de Fátima Palma / Clara Rodrigues / Susana Gómez / Lígia Rafael

\section{Arte Rupestre}

497 Os inventários de arte rupestre em Portugal Mila Simões de Abreu

513 O projeto FIRST-ART - conservação, documentação e gestão das primeiras manifestações de arte rupestre no Sudoeste da Península Ibérica: as grutas do Escoural e Maltravieso Sara Garcês / Hipólito Collado / José Julio García Arranz / Luiz Oosterbeek / António Carlos Silva / Pierluigi Rosina / Hugo Gomes / Anabela Borralheiro Pereira / George Nash / Esmeralda Gomes / Nelson Almeida / Carlos Carpetudo

523 Trabalhos de documentação de arte paleolítica realizados no âmbito do projeto PalæoCôa André Tomás Santos / António Fernando Barbosa / Luís Luís / Marcelo Silvestre / Thierry Aubry

537 Imagens fantasmagóricas, silhuetas elusivas: as figuras humanas na arte do Paleolítico Superior da região do Côa Mário Reis

$55^{1}$ Os motivos zoomórficos representados nas placas de tear de Vila Nova de São Pedro (Azambuja, Portugal) Andrea Martins / César Neves / José M. Arnaud / Mariana Diniz

571 Arte Rupestre do Monte de Góios (Lanhelas, Caminha). Síntese dos resultados dos trabalhos efectuados em 2007-2009 Mário Varela Gomes

599 Gravuras rupestres de barquiformes no Monte de S. Romão, Guimarães, Noroeste de Portugal Daniela Cardoso

613 Círculos segmentados gravados na Bacia do Rio Lima (Noroeste de Portugal): contributos para o seu estudo Diogo Marinho / Ana M.S. Bettencourt / Hugo Aluai Sampaio

631 Equídeos gravados no curso inferior do Rio Mouro, Monção (NW Portugal). Análise preliminar Coutinho, L.M. / Bettencourt, A.M.S / Sampaio, Hugo A.S

645 Paletas na Arte Rupestre do Noroeste de Portugal. Inventário preliminar Bruna Sousa Afonso / Ana M. S. Bettencourt / Hugo A. Sampaio 


\section{Pré-História}

661 O projeto Miño/Minho: balanço de quatro anos de trabalhos arqueológicos Sérgio Monteiro-Rodrigues / João Pedro Cunha-Ribeiro / Eduardo Méndez-Quintas / Carlos Ferreira / Pedro Xavier / José Meireles / Alberto Gomes / Manuel Santonja / Alfredo Pérez-González

677 A ocupação paleolítica da margem esquerda do Baixo Minho: a indústria lítica do sítio de Pedreiras 2 (Monção, Portugal) e a sua integração no contexto regional Carlos Ferreira / João Pedro Cunha-Ribeiro / Sérgio Monteiro-Rodrigues / Eduardo Méndez-Quintas / Pedro Xavier / José Meireles / Alberto Gomes / Manuel Santonja / Alfredo Pérez-González

693 O sítio acheulense do Plistocénico médio da Gruta da Aroeira Joan Daura / Montserrat Sanz / Filipa Rodrigues / Pedro Souto / João Zilhão

703 As sociedades neandertais no Barlavento algarvio: modelos preditivos com recurso aos SIG

Daniela Maio

715 A utilização de quartzo durante o Paleolítico Superior no território dos vales dos rios Vouga e Côa

Cristina Gameiro / Thierry Aubry / Bárbara Costa / Sérgio Gomes / Luís Luís / Carmen Manzano / André Tomás Santos

733 Uma perspetiva diacrónica da ocupação do concheiro do Cabeço da Amoreira (Muge, Portugal) a partir da tecnologia lítica Joana Belmiro / João Cascalheira / Célia Gonçalves

745 Novos dados sobre a Pré-história Antiga no concelho de Palmela. A intervenção arqueológica no sítio do Poceirão I

Michelle Teixeira Santos

757 Problemas em torno de Datas Absolutas Pré-Históricas no Norte do Alentejo Jorge de Oliveira

771 Povoamento pré-histórico nas áreas montanhosas do NO de Portugal: o Abrigo 1 de Vale de Cerdeira Pedro Xavier / José Meireles / Carlos Alves

783 Apreciação do povoamento do Neolítico Inicial na Baixa Bacia do Douro. A Lavra I (Serra da Aboboreira) como caso de estudo Maria de Jesus Sanches

797 O Processo de Neolitização na Plataforma do Mondego: os dados do Sector C do Outeiro dos Castelos de Beijós (Carregal do Sal)

João Carlos de Senna-Martinez / José Manuel Quintã Ventura / Andreia Carvalho / Cíntia Maurício

823 Novos trabalhos na Lapa da Bugalheira (Almonda, Torres Novas) Filipa Rodrigues / Pedro Souto / Artur Ferreira / Alexandre Varanda / Luís Gomes / Helena Gomes / João Zilhão

837 A pedra polida e afeiçoada do sítio do Neolítico médio da Moita do Ourives (Benavente, Portugal)

César Neves

857 Casal do Outeiro (Encarnação, Mafra): novos contributos para o conhecimento do povoamento do Neolítico final na Península de Lisboa.

Cátia Delicado / Carlos Maneira e Costa / Marta Miranda / Ana Catarina Sousa

873 Stresse infantil, morbilidade e mortalidade no sítio arqueológico do Neolítico Final/ Calcolítico ( $4^{\circ}$ e $3^{\circ}$ milénio a.C.) do Monte do Carrascal 2 (Ferreira do Alentejo, Beja) Liliana Matias de Carvalho / Sofia N. Wasterlain 
885 Come together: O Conjunto Megalítico das Motas (Monção, Viana do Castelo) e as expressões Campaniformes do Alto Minho Ana Catarina Basílio / Rui Ramos

899 Trabalhos arqueológicos no sítio Calcolítico da Pedreira do Poio Carla Magalhães / João Muralha / Mário Reis / António Batarda Fernandes

913 O sítio arqueológico de Castanheiro do Vento. Da arquitectura do sítio à arquitectura de um território João Muralha Cardoso

925 Estudo zooarqueológico das faunas do Calcolítico final de Vila Nova de São Pedro (Azambuja, Portugal): Campanhas de 2017 e 2018 Cleia Detry / Ana Catarina Francisco / Mariana Diniz / Andrea Martins / César Neves / José Morais Arnaud

943 As faunas depositadas no Museu Arqueológico do Carmo provenientes de Vila Nova de São Pedro (Azambuja): as campanhas de 1937 a 1967 Ana Catarina Francisco / Cleia Detry / César Neves / Andrea Martins / Mariana Diniz / José Morais Arnaud

959 Análise funcional de material lítico em sílex do castro de Vila Nova de S. Pedro (Azambuja, Portugal): uma primeira abordagem Rafael Lima

971 O recinto da Folha do Ouro 1 (Serpa) no contexto dos recintos de fossos calcolíticos alentejanos

António Carlos Valera / Tiago do Pereiro / Pedro Valério / António M. Monge Soares

\section{Proto-História}

987 Produção de sal marinho na Idade do Bronze do noroeste Português. Alguns dados para uma reflexão

Ana M. S. Bettencourt / Sara Luz / Nuno Oliveira / Pedro P. Simões / Maria Isabel C. Alves / Emílio Abad-Vidal

1001 A estátua-menir do Pedrão ou de São Bartolomeu do Mar (Esposende, noroeste de Portugal) no contexto arqueológico da fachada costeira de entre os rios Neiva e Cávado Ana M. S. Bettencourt / Manuel Santos-Estévez / Pedro Pimenta Simões / Luís Gonçalves

1015 O Castro do Muro (Vandoma/Baltar, Paredes) - notas para uma biografia de ocupação da Idade do Bronze à Idade Média

Maria Antónia D. Silva / Ana M. S. Bettencourt / António Manuel S. P. Silva / Natália Félix

1031 Do Bronze Final à Idade Média - continuidades e hiatos na ocupação de Povoados em Oliveira de Azeméis João Tiago Tavares / Adriaan de Man

1041 As faunas do final da Idade do Bronze no Sul de Portugal: leituras desde o Outeiro do Circo (Beja)

Nelson J. Almeida / Íris Dias / Cleia Detry / Eduardo Porfírio / Miguel Serra

1055 A Espada do Monte das Oliveiras (Serpa) - uma arma do Bronze Pleno do Sudoeste Rui M. G. Monge Soares / Pedro Valério / Mariana Nabais / António M. Monge Soares

1065 São Julião da Branca (Albergaria-a-Velha) - Investigação e valorização de um povoado do Bronze Final

António Manuel S. P. Silva / Paulo A. P. Lemos / Sara Almeida e Silva / Edite Martins de Sá

1083 Do castro de S. João ao Mosteiro de Santa Clara: notícia de uma intervenção arqueológica, em Vila do Conde Rui Pinheiro 
1095 O castro de Ovil (Espinho), um quarto de século de investigação - resultados e questões em aberto

Jorge Fernando Salvador / António Manuel S. P. Silva

1111 O Castro de Salreu (Estarreja), um povoado proto-histórico no litoral do Entre Douro e Vouga

Sara Almeida e Silva / António Manuel S. P. Silva / Paulo A. P. Lemos / Edite Martins de Sá

1127 Castro de Nossa Senhora das Necessidades (Sernancelhe): uma primeira análise artefactual Telma Susana O. Ribeiro

${ }_{1141}$ A cividade de Bagunte. O estado atual da investigação Pedro Brochado de Almeida

1153 Zoomorfos na cerâmica da Idade do Ferro no NW Peninsular: inventário, cronologias e significado Nuno Oliveira / Cristina Seoane

1163 Vasos gregos em Portugal: diferentes maneiras de contar a história do intercâmbio cultural na Idade do Ferro

Daniela Ferreira

1175 Os exotica da necrópole da Idade do Ferro do Olival do Senhor dos Mártires (Alcácer do Sal) no seu contexto regional

Francisco B. Gomes

\section{Antiguidade Clássica e Tardia}

1191 O uso de madeira como combustível no sítio da Quinta de Crestelos (Baixo Sabor): da Idade do Ferro à Romanização Filipe Vaz / João Tereso / Sérgio Simões Pereira / José Sastre / Javier Larrazabal Galarza / Susana Cosme / José António Pereira / Israel Espi

1207 Cultivos de Época Romana no Baixo Sabor: continuidade em tempos de mudança? João Pedro Tereso / Sérgio Simões Pereira / Filipe Santos / Luís Seabra / Filipe Vaz

1221 A casa romana na Hispânia: aplicação dos modelos itálicos nas províncias ibéricas Fernanda Magalhães / Diego Machado / Manuela Martins

1235 As pinturas murais romanas da Rua General Sousa Machado, n. ${ }^{5}$ 1, Chaves José Carvalho

1243 Trás do Castelo (Vale de Mir, Pegarinhos, Alijó) - Uma exploração agrícola romana do Douro

Tony Silvino / Pedro Pereira

1255 A sequência de ocupação no quadrante sudeste de Bracara Augusta: as transformações de uma unidade doméstica Lara Fernandes / Manuela Martins

1263 Os Mosaicos com decoração geométrica e geométrico-vegetalista dos sítios arqueológicos da área do Conuentus Bracaraugustanus. Novas abordagens quanto à conservação, restauro, decoração e datação Maria de Fátima Abraços / Licínia Wrench

1277 “Casa Romana” do Castro de São Domingos (Cristelos, Lousada): Escavação, Estudo e Musealização Paulo André de P. Lemos

1291 A arqueobotânica no Castro de Guifões (Matosinhos, Noroeste de Portugal): O primeiro estudo carpológico

Luís Seabra / Andreia Arezes / Catarina Magalhães / José Varela / João Pedro Tereso 
1305 Um Horreum Augustano na Foz do Douro (Monte do Castelo de Gaia, Vila Nova de Gaia) Rui Ramos

1311 Ponderais romanos na Lusitânia: padrões, formas, materiais e contextos de utilização Diego Barrios Rodríguez

1323 Um almofariz centro-itálico na foz do Mondego

Marco Penajoia

1335 Estruturas romanas de Carnide - Lisboa Luísa Batalha / Mário Monteiro / Guilherme Cardoso

1347 O contexto funerário do sector da "necrópole NO" da Rua das Portas de S. Antão (Lisboa): o espaço, os artefactos, os indivíduos e a sua interconectividade na interpretação do passado Sílvia Loja, José Carlos Quaresma, Nelson Cabaço, Marina Lourenço, Sílvia Casimiro, Rodrigo Banha da Silva, Francisca Alves-Cardoso

${ }_{1361}$ Povoamento em época Romana na Amadora - resultados de um projeto pluridisciplinar Gisela Encarnação / Vanessa Dias

1371 A Arquitectura Residencial em Mirobriga (Santiago do Cacém): contributo a partir de um estudo de caso Filipe Sousa / Catarina Felício

${ }_{1385}$ O fim do ciclo. Saneamento e gestão de resíduos nos edifícios termais de Mirobriga (Santiago do Cacém)

Catarina Felício / Filipe Sousa

1399 Balsa, Topografia e Urbanismo de uma Cidade Portuária Vítor Silva Dias / João Pedro Bernardes / Celso Candeias / Cristina Tété Garcia

1413 No Largo das Mouras Velhas em Faro (2017): novas evidências da necrópole norte de Ossonoba e da sua ocupação medieval Ricardo Costeira da Silva / Paulo Botelho / Fernando Santos / Liliana Nunes

1429 Instrumentos de pesca recuperados numa fábrica de salga em Ossonoba (Faro) Inês Rasteiro / Ricardo Costeira da Silva / Paulo Botelho

1439 A Necrópole Romana do Eirô, Duas Igrejas (Penafiel): intervenção arqueológica de 2016 Laura Sousa / Teresa Soeiro

1457 Ritual, descarte ou afetividade? A presença de Canis lupus familiaris na Necrópole Noroeste de Olisipo (Lisboa)

Beatriz Calapez Santos / Sofia Simões Pereira / Rodrigo Banha da Silva / Sílvia Casimiro / Cleia Detry / Francisca Alves Cardoso

1467 Dinâmicas económicas em Bracara na Antiguidade Tardia Diego Machado / Manuela Martins / Fernanda Magalhães / Natália Botica

1479 Cerâmicas e Vidros da Antiguidade Tardia do Edifício sob a Igreja do Bom Jesus (Vila Nova de Gaia) Joaquim Filipe Ramos

1493 Novos contributos para a topografia histórica de Mértola no período romano e na Antiguidade Tardia Virgílio Lopes

\section{8. Época Medieval}

1511 Cerâmicas islâmicas no Garb setentrional "português": algumas evidências e incógnitas Constança dos Santos / Helena Catarino / Susana Gómez / Maria José Gonçalves / Isabel Inácio / Gonçalo Lopes / Jacinta Bugalhão / Sandra Cavaco / Jaquelina Covaneiro / Isabel Cristina Fernandes / Ana Sofia Gomes 
1525 Contributo para o conhecimento da cosmética islâmica, em Silves, durante a Idade Média Rosa Varela Gomes

1537 Yábura e o seu território - uma análise histórico-arqueológica de Évora entre os séculos VIII-XII José Rui Santos

1547 A encosta sul do Castelo de Palmela - resultados preliminares da escavação arqueológica Luís Filipe Pereira / Michelle Teixeira Santos

1559 A igreja de São Lourenço (Mouraria, Lisboa): um conjunto de silos e de cerâmica medieval islâmica

Andreia Filipa Moreira Rodrigues

1571 O registo material de movimentações populacionais no Médio Tejo, durante os séculos XII-XIII. Dois casos de "sunken featured buildings", nos concelhos de Cartaxo e Torres Novas Marco Liberato / Helena Santos / Nuno Santos

1585 O nordeste transmontano nos alvores da Idade média. Notas para reflexão Ana Maria da Costa Oliveira

1601 Sepulturas escavadas na rocha do Norte de Portugal e do Vale do Douro: primeiros resultados do Projecto SER-NPVD

Mário Jorge Barroca / César Guedes / Andreia Arezes / Ana Maria Oliveira

1619 "Portucalem Castrum Novum" entre o Mediterrâneo e o Atlântico: o estudo dos materiais cerâmicos alto-medievais do arqueossítio da rua de D. Hugo, nํ. 5 (Porto) João Luís Veloso

1627 A Alta Idade Média na fronteira de Lafões: notas preliminares sobre a Arqueologia no Concelho de Vouzela

Manuel Luís Real / Catarina Tente

1641 Um conjunto cerâmico medieval fora de portas: um breve testemunho aveirense Susana Temudo

${ }_{1651}$ Os Lóios do Porto: uma perspetiva integrada no panorama funerário da Baixa Idade Média à Época Moderna em meios urbanos em Portugal

Ana Lema Seabra

1659 O Caminho Português Interior de Santiago como eixo viário na Idade Média Pedro Azevedo

1665 Morfologia Urbana: Um exercício em torno do Castelo de Ourém André Donas-Botto / Jaqueline Pereira

1677 Intervenção arqueológica na Rua Marquês de Pombal/Largo do Espírito Santo (Bucelas, Loures)

Florbela Estêvão / Nathalie Antunes-Ferreira / Dário Ramos Neves / Inês Lisboa

1691 O Cemitério Medieval do Poço do Borratém e a espacialidade funerária na cidade de Lisboa Inês Belém / Vanessa Filipe / Vasco Noronha Vieira / Sónia Ferro / Rodrigo Banha da Silva

1705 Um Espaço Funerário Conventual do séc. XV em Lisboa: o caso do Convento de São Domingos da Cidade Sérgio Pedroso / Sílvia Casimiro / Rodrigo Banha da Silva / Francisca Alves Cardoso

\section{9. Época Moderna e Contemporânea}

1721 Arqueologia Moderna em Portugal: algumas reflexões críticas em torno da quantificação de conjuntos cerâmicos e suas inferências históricas e antropológicas Rodrigo Banha da Silva / André Bargão / Sara da Cruz Ferreira

1733 Faianças de dois contextos entre os finais do século XVI e XVIII do Palácio dos Condes de Penafiel, Lisboa

Martim Lopes / Tomás Mesquita 
1747 Um perfil de consumo do século XVIII na foz do Tejo: O caso do Mercado da Ribeira, Lisboa Sara da Cruz Ferreira / Rodrigo Banha da Silva / André Bargão

1761 Os Cachimbos dos Séculos XVII e XVIII do Palácio Mesquitela e Convento dos Inglesinhos (Lisboa)

Inês Simão / Marina Pinto / João Pimenta / Sara da Cruz Ferreira / André Bargão / Rodrigo Banha da Silva

1775 "Tomar os fumos da erua que chamão em Portugal erua sancta». Estudo de Cachimbos provenientes da Rua do Terreiro do Trigo, Lisboa

Miguel Martins de Sousa / José Pedro Henriques / Vanessa Galiza Filipe

1787 Cachimbos de Barro Caulínitico da Sé da Cidade Velha (República de Cabo Verde)

Rodrigo Banha da Silva / João Pimenta / Clementino Amaro

1801 Algumas considerações sobre espólio não cerâmico recuperado no Largo de Jesus (Lisboa) Carlos Boavida

1815 Adereços de vidro, dos séculos XVI-XVIII, procedentes do antigo Convento de Santana de Lisboa (anéis, braceletes e contas)

Joana Gonçalves / Rosa Varela Gomes / Mário Varela Gomes

1837 Da ostentação, luxo e poder à simplicidade do uso quotidiano: arqueologia e simbologia de joias e adornos da Idade Moderna Portuguesa Jéssica Iglésias

1849 Os amuletos em Portugal - dos objetos às superstições: o coral vermelho Alexandra Vieira

1865 Cerâmicas de Vila Franca de Xira nos séculos XV e XVI Eva Pires

1879 «Não passa por teu o que me pertence». Marcas de individualização associadas a faianças do Convento de Nossa Senhora de Aracoeli, Alcácer do Sal Catarina Parreira / Íris Fragoso / Miguel Martins de Sousa

1891 Cerâmica de Leiria: alguns focos de produção

Jaqueline Pereira / André Donas-Botto

1901 Os Fornos na Rua da Biquinha, em Óbidos Hugo Silva / Filipe Oliveira

1909 A casa de Pêro Fernandes, contador dos contos de D. Manuel I: o sítio arqueológico da Silha do Alferes, Seixal (século XVI) Mariana Nunes Ferreira

1921 O Alto da Vigia (Sintra) e a vigilância e defesa da costa Alexandre Gonçalves / Sandra Santos

1937 O contexto da torre sineira da Igreja de Santa Maria de Loures Paulo Calaveira / Martim Lopes

1949 A Necrópole do Hospital Militar do Castelo de São Jorge e as práticas funerárias na Lisboa de Época Moderna Susana Henriques / Liliana Matias de Carvalho / Ana Amarante / Sofia N. Wasterlain

1963 SAND - Sarilhos Grandes Entre dois Mundos: o adro da Igreja e a Paleobiologia dos ossos humanos recuperados

Paula Alves Pereira / Roger Lee Jesus / Bruno M. Magalhães

1975 Expansão urbana da vila de Cascais no século XVII e XVIII: a intervenção arqueológica na Rua da Vitória no 15 a 17

Tiago Pereira / Vanessa Filipe

1987 Novos dados para o conhecimento do Urbanismo de Faro em época Moderna Ana Rosa 
1995 Um exemplo de Arqueologia Urbana em Alcoutim: o Antigo Edifício dos CTT Marco Fernandes / Marta Dias / Alexandra Gradim / Virgílio Lopes / Susana Gómez Martínez

2007 Palácio dos Ferrazes (Rua das Flores/Rua da Vitória, Porto): a cocheira de Domingos Oliveira Maia

Francisco Raimundo

2021 As muitas vidas de um edifício urbano: História, Arqueologia e Antropologia no antigo Recreatório Paroquial de Penafiel Helena Bernardo / Jorge Sampaio / Marta Borges

2035 O convento de Nossa Senhora da Esperança de Ponta Delgada: o contributo da arqueologia para o conhecimento de um monumento identitário João Gonçalves Araújo / N’Zinga Oliveira

2047 Arqueologia na ilha do Corvo... em busca da capela de Nossa Senhora do Rosário Tânia Manuel Casimiro / José Luís Neto / Luís Borges / Pedro Parreira

2059 Perdidos à vista da Costa. Trabalhos arqueológicos subaquáticos na Barra do Tejo Jorge Freire / José Bettencourt / Augusto Salgado

2071 Arqueologia marítima em Cabo Verde: enquadramento e primeiros resultados do projecto CONCHA

José Bettencourt / Adilson Dias / Carlos Lima / Christelle Chouzenoux / Cristóvão Fonseca / Dúnia Pereira / Gonçalo Lopes / Inês Coelho / Jaylson Monteiro / José Lima / Maria Eugénia Alves / Patrícia Carvalho / Tiago Silva

2085 Trabalhos arqueológicos na Cidade Velha (Ribeira Grande de Santiago, Cabo Verde): reflexões sobre um projecto de investigação e divulgação patrimonial André Teixeira / Jaylson Monteiro / Mariana Mateus / Nireide Tavares / Cristovão Fonseca / Gonçalo C. Lopes / Joana Bento Torres / Dúnia Pereira / André Bargão / Aurélie Mayer / Bruno Zélie / Carlos Lima / Christelle Chouzenoux / Inês Henriques / Inês Pinto Coelho / José Lima / Patrícia Carvalho / Tiago Silva

2103 A antiga fortificação de Quelba / Khor Kalba (E.A.U.). Resultados de quatro campanhas de escavações, problemáticas e perspectivas futuras Rui Carita / Rosa Varela Gomes / Mário Varela Gomes / Kamyar Kamyad

2123 Colónias para homens novos: arqueologia da colonização agrária fascista no noroeste ibérico Xurxo Ayán Vila / José Mạ . Señorán Martín 


\title{
VALPAÇOS - UMA NOVA CARTA ARQUEOLÓGICA
}

\author{
Pedro Pereira ${ }^{1}$, Maria de Fátima Casares Machado ${ }^{2}$
}

\begin{abstract}
RESUMO
Valpaços é recente no panorama administrativo português. O despovoamento do antigo concelho de Monforte de Rio Livre levou à reformulação da estrutura administrativa do território entre a serra da Padrela e o Rabaçal, entre Chaves e Mirandela, com a extinção do concelho de Carrazedo de Montenegro e a apropriação de territórios de concelhos vizinhos.

Desde a agregação, num só território, das terras frias e quentes, de uma multiplicidade de realidades geológicas, de fauna e flora, mas também arqueológicas. Em 200o, foi realizada uma carta arqueológica para o território de Valpaços. No entanto, o presente trabalho tem como objectivo primário operacionalizar os mecanismos de preservação do património do concelho, promovendo a sensibilização para um legado frágil.

O trabalho que tem vindo a ser realizado pelo município de Valpaços tem como objectivo não só identificar novos sítios, mas também re-localizar e proteger o património arqueológico conhecido.

Palavras-chave: Valpaços, Carta Arqueológica.
\end{abstract}

\begin{abstract}
Valpaços is a very recent administrative division in portuguese history. The abandonment that Monforte de Rio Livre suffered made it necessary to create a new administrative area, between the Padrela Hills and the Rabaçal, in between Chaves and Mirandela, extinguishing Carrazedo de Montenegro and incorportating adjoining territories.

Ever since the agregation, in a single territory, of the so called "terras frias" and "terras quentes, of multiple geological, faunistic and floral realities, but also by archaeological challenges. The current research has the main objective to update the heritage protection mechanisms of the territory, while promoting its fragility. The work being carried out by the Valpaços city hall is centered not only on identifying new sites, but also protecting known ones.
\end{abstract}

Keywords: Valpaços, Archaeological Chart.

\section{VALPAÇOS, UM TERRITÓRIO MULTI-FACETADO}

A primeira questão que devemos colocar é a de porquê de uma nova carta arqueológica para Valpaços? Adérito de Freitas, que tem estudado o território de Valpaços nas últimas quatro décadas, publicou uma primeira súmula deste conhecimento adquirido em 2001, na Carta Arqueológica do Concelho de Valpaços. Todavia, o autor é o primeiro a declarar que não teve a oportunidade de estudar a fundo a larga maioria dos sítios e materiais. Paralelamente, ao longo das duas décadas subsequentes, novos estudos têm vindo a ser realizados sobre o território, tanto de Valpaços (FREITAS, 2001; 2010 e 2011) como dos concelhos limítrofes, permitindo uma melhor perceção sobre a evolução da ocupação humana desta zona (CARVALHO et allii, 2017).

O património arqueológico em Portugal, a sua divulgação e, sobretudo, a sua proteção, tem recebido atenção por parte das estruturas da tutela mas também outros órgãos públicos e privados. Com a ascensão do turismo, o património arqueológico, em conjunto com outros elementos, ganha uma nova dimensão. Ao mesmo tempo, tratando-se de um património extremamente frágil, a divulgação

1. CITCEM; pedro.abrunhosa.pereira@gmail.com.

2. Câmara Municipal de Valpaços; fatimaxado@gmail.com. 
e promoção do património arqueológico entre a população local faz com que a mesma se aproprie dele, vendo-o como uma mais valia para a sua região e protegendo-o.

O espaço que abrange nos nossos dias o concelho de Valpaços é fruto de uma criação administrativa relativamente recente. Parcialmente dentro de espaços geológicos e climáticos extremamente distintos, Valpaços possui uma variedade pouco usual de condições geográficas, aumentando a riqueza actual do património arqueológico presente no território (Figura 1).

Território multifacetado, a Ocidente, Valpaços é geologicamente marcado pelos xistos, pertence a uma realidade climática designada como Terra Fria, com uma maior pluviosidade e uma temperatura média anual relativamente baixa. A Oriente, o território é pontihado pelo granito. Com a aproximação do leito do Rabaçal, o clima torna-se mais próximo do concelho vizinho de Mirandela, da Terra Quente, com menor pluviosidade ao longo do ano e temperaturas mais altas durante o Verão, ainda que com um Inverno rigoroso. Este mosaico de realidades climáticas e geológicas é bem visível quando atravessamos o concelho, sobretudo através das práticas agrícolas, adaptadas a cada zona. Paralelamente, ao longo dos tempos, o ser humano tem preferido determinados território para se estabelecer, seja durante a Pré-História, em que zonas de altitude média mais baixa no concelho são de maior predileção, próximas de cursos de água, seja durante a Romanização, com uma adaptação aos novos paradigmas da realidade administrativa e viária vigente.

Quando abordamos um território é necessário com-preender também que muitos dos sítios escolhidos pelo Homem como habitat têm uma longa ou longas ocupações, podendo ter existido rupturas nas mesmas. Em muitos casos, os povoados proto-históricos possuiam já uma ocupação humana anterior à Idade do Ferro. Muitos são romanizados, outros, são abandonados. Existem ainda casos em que se verifica uma ocupação durante a Idade do Ferro e novamente uma ocupação durante momentos, sobretudo iniciais, da Idade Média. Em muitos casos, a população local poderia ter ainda a consciência da existência de uma estrutura defensiva, ainda que abandonada durante o período romano, que poderia servir de abrigo.

\section{O TERRITÓRIO DE VALPAÇOS ANTES DE SER VALPAÇOS}

A Pré-História é o período que menos conhecemos quando falamos sobre a História de Valpaços. Embora vários investigadores se tenham debruçado sobre o tema no território (entre outros podemos citar aqui os trabalhos de Maria de Jesus Sanches e Joana Ribeiro (SANCHES 1994 e 1997 e RIBEIRO, 2007.), os vestígios são extremamente ténues se excluirmos os monumentos funerários, de cronologia relativamente recente dentro do paradigma da Pré-História, e a arte rupestre. São praticamente desconhecidos núcleos de habitat humano, com a exlusão do Outeiro do Homem, em Argeriz, identificado por Adérito de Freitas. Ao longo das prospecções realizadas no decurso do presente trabalho, foi identificado um outro possível núcleo de ocupação, no vale do Rabaçal, onde no decurso de trabalhos agrícolas foram recolhidos machados em anfibolitor ${ }^{3}$.

Paralelamente, a falta de intervenções no terreno, sondagens ou escavações, fazem com que as datações dos sítios pré-históricos de Valpaços sejam apenas relativas e passíveis de re-interpretações (Figura 2).

Nos últimos anos foram publicados vários trabalhos centrados na questão da arte rupestre presente em Valpaços (FREITAS, 2011; SANCHES 1994 e 1997; RIBEIRO, 2007 e 2017). Tal como referimos anteriormente, as representações artísticas datáveis da Pré-História concentram-se nas zonas mais a Sul, tradicionalmente mais temperadas, do concelho. São, na sua larga maioria gravuras, com representações simples de covinhas, podomorfos e serpentiformes. No entanto, estes tipos de representações são também conhecidas mais a Norte, no sítio da Saínça, em Tinhela, ou no conjunto de gravuras do Castro de Nossa Senhora da Ribeira, em Lampaça, Bouçoais (RIBEIRO, 2007), mas também em pequenos núcleos, como sucede com os vários conjuntos

\footnotetext{
3. Localizadas em terrenos próximos da aldeia abandonada do Cachão, o proprietário do terreno e fiel depositário dos materiais permitiu-nos registá-los. Em visita à zona, muito alterada por trabalhos agrícolas durante o século XX, é também possível observar a existência de uma série de abrigos, embora sem traços visíveis de ocupação. Foi ainda nesta zona que foi registado um grande painel com gravuras de tipo "covinha" no decurso de um Estudo de Impacto Ambiental (NETO e CHAVES, 2011). Infelizmente, as coordenadas do sítio estão incorretas e não foi possível detetar o local exato do painel.
} 
conhecidos em povoados fortificados, como no Castro de Vilanova e no Castro de Santa Valha (FREITAS, 2011). As representações figurativas e pinturas são mais escassas, embora sejam conhecidos no concelho alguns exemplos, mais uma vez concentrados na zona Sul do mesmo. Ao mesmo tempo, a leitura destes conjuntos deve tomar em conta as zonas de ribeiras e rios onde as mesmas se encontram, formando conjuntos que decorrem de Valpaços até Mirandela e Murça, sobretudo na zona da Serra de Passos (RIBEIRO, 2017 in CARVALHO et allii, 2017.).

A Idade do Ferro, ou Proto-história, é também um momento complexo a decifrar, embora neste caso tenham sido realizadas intervenções mais extensas no terreno, que permitiram ter alguns dados que permitem a leitura de alguns elementos sobre o período. No entanto, de entre os 27 povoados tradicionalmente identificados como proto-históricos no território de Valpaços, muitos não possuem material de superfície nem estruturas passíveis de os identificar como tais, muitas vezes sendo visíveis apenas materiais de cronologia romana, como tegulae e imbrex. Paralelamente, muitos destes sítios possuem ocupações anteriores, como aparenta ser o caso do Castro de Santa Valha que possui uma série de gravuras rupestres datáveis de momentos anteriores à Idade do Ferro (FREITAS, 2011). Ao mesmo tempo, muitos destes povoados aparentam sofrer momentos de re-ocupação, tal como sucede noutros casos no Noroeste peninsular, sobretudo durante a Alta Idade Média (Figura 3).

A ocupação da proto-história em Valpaços aparenta pautar-se sobretudo com os povoados fortificados. No entanto, mesmo no caso deste tipo de estrutura, são lisíveis alguns aspectos interessantes no território. No caso do sítio das Fragas da Cerca, por exemplo, é notória a presença de enormes conheiras no sopé das estruturas defensivas, próximas do ribeiro que bordeja a face Oeste do povoado, o que, associada à intervenção do Serviço Nacional de Minas na zona há algumas décadas (CASTRO e CORDEIRO, 1963), poderá indicar uma vocação de mineração presente na zona.

Um estudo de visualizações entre os vários povoados fortificados permitiu ainda definir, ao nível visual, que os mesmos poderão constituír partes de grupos, existindo certamente contactos próximos entre eles. Para além dos povoados fortificados com elementos patentes de uma realidade histórica da Proto-História, existem poucos outros achados que po- derão ser associados, com algum grau de certeza, a este período. Dois deles consistiram em achados fortuítos, de tesouros. O primeiro, bastante conhecido, é o chamado tesouro de Lebução, no qual estão integradas uma série de jóias datáveis da Idade do Ferro. O segundo, menos conhecido, consiste num torque, em exposição no Museu de Numismática de Vila Real, descoberto nos arredores de Rendufe. Para além destes conjuntos, algumas gravuras rupestres, sobretudo quando inseridas nas áreas de castros, poderão ser datáveis da Idade do Ferro: é o caso dos blocos do Castro de Ribas, um dos quais com um elemento circular e motivos radiais e outro com um motivo em espiral, infelizmente em paradeiro desconhecido actualmente. Neste caso específico, tal como outros investigadores propuseram (FREITAS, 2001), poderá tratar-se de uma re-utilização de elementos arquitectónicos. Paralelamente, são conhecidos casos em que as muralhas recebiam grafitos, como sucede no Castro de Yecla de Yeltes, em Castilla y León, Espanha.

Finalmente, a ocupação datável da Idade do Ferro no concelho é notória, sobretudo através da grande quantidade de povoados fortificados que sobreviveram. No entanto, se a prospecção arqueológica permite elacções sobre alguns pontos, comparando através de paralelos conhecidos noutros territórios, serão necessárias sondagens, sobretudo nos castros, para se poder ter uma melhor compreensão de como se desenvolveram e como se procede à transição com o período romano e medieval.

O período Romano é de leitura mais simples sobre o território de Valpaços, ainda que com constrangimentos similares aos patentes nos restantes períodos. Os materiais visíveis em prospeção são menos passíveis a interpretações e as estruturas são, normalmente, mais estandardizadas. Um dos elementos fulcrais que nos permite ler o território de Valpaços no período romano é a rede viária. $O$ facto de uma série de estruturas viárias romanas terem sobrevivido, em maior ou menor escala, permitiu a identificação de uma série de novos sítios ao longo dos seus percursos. Paralelamente, conseguimos, conjugando estudos anteriores sobre as redes viárias (BARRADAS, 1956, FREITAS, 2001 e TEIXEIRA, 1996), e a localização de sítios com ocupação humana no concelho, compreender como é que o território actual do mesmo estaria organizado no período romano.

A maior parte dos sítios comprovadamente romanos no concelho de Valpaços consistem em manchas de 
materiais, de maior ou menor dimensão, localizadas sobretudo em zonas próximas das redes viárias, e em povoados indígenas que foram romanizados. Existem três eixos viários com alguma monumentalidade que atravessam Valpaços: o iter XVII, descrito no Itinerário de Antonino, a via que parte de Aquae Flaviae ao Douro, passando por Três Minas, a via que ligava Formil a Três Minas e, numa menor escala, a via entre a actual povoação de Friões e Aquae Flaviae. No decurso da prospecção realizada ao longo destas vias, foi possível identificar uma série de derivações às mesmas e, em alguns casos, como sucedeu com Milagres II, sítios inéditos. Com a atualização do estado de conhecimentos sobre os eixos viários do concelho, é possível ter uma melhor leitura sobre o território de Valpaços, tanto no período romano como imediatamente antes e depois do mesmo. Alguns dos eixos viários de período clássico continuação a ter alguma importância até aos nossos dias, como é o caso de grande parte do iter XVII durante a sua passagem pela povoação de Sá, coberto hoje em dia com um piso de alcatrão.

Os elementos associados ao mundo dos mortos, como as aras e depósitos votivos, são também notórias no território de Valpaços, sobretudo tendo em conta que a sua concentração normalmente se dá próxima de eixos viários. Dividem-se em três conjuntos principais: um a Norte, acompanhando a via entre Formil e Três Minas, na zona de Lebução; um segundo, mais próximo da fronteira com Chaves, na mesma via; e um terceiro, entre a via Formil e Três Minas e a via que parte de Aquae Flaviae ao Douro, muito possivelmente uma via secundária que foi substituída pela construção da estrada M541.

Relativamente ao habitat, existem 14 povoados fortificados que possuem indícios de superfície de romanização, embora não seja possível delinear um quadro mais completo sem intervenções no terreno. Paralelamente, existem 39 manchas de superfície com materiais de cronologia romana, estando uma dezena dos mesmos em zonas próximas de castros romanizados. Existem também referências de achados isolados, como sucedeu com o conjunto de materiais descoberto em Valpaços e em depósito no Museu Abade de Baçal, em Bragança. Embora muito possivelmente estas peças possam provir de uma necrópole, a falta de dados sobre o contexto em que as mesmas foram descoberta impede uma interpretação mais cuidada (Figura 4).

Com o dealbar do período romano e a estrutura ad- ministrativa existente, o território conhecido hoje com Valpaços sofrerá uma série de alterações. A chegada de povos bárbaros ao território por volta de 409 da nossa Era será pouco linear. Idácio, o então bispo de Aquae Flaviae, narra-nos um panorama de fome, guerra, desolação e violência. No entanto, devemos diferenciar o colapso das estruturas, administrativas e sociais e a sua substituição por uma nova ordem, em oposto ao mundo latino em que Idácio vivia.

As lutas de poder entre os vários povos bárbaros terminam com a estabilidade concedida pela criação do Reino Suevo, em 429. Este último terminará cerca de século e meio mais tarde, com a unificação, em 585 , com o Reino Visigodo. As invasões muçulmanas de 711 irão criar um novo momento de instabilidade, ampliado com a reconquista cristã. Será apenas durante o reinado de Ordonho I, entre 850 e 866, que o processo de reconquista, repovoamento e re-organização dos territórios será mais efetivo. Pouco após este reinado, Chaves é conquistada, em 872. O espaço é dividido entre territoria, elementos territoriais decalcados da organização diocesana, e civitates, territórios que são dominados por um nobre. O período conturbado da Alta Idade Média deixará marcas no território e nas suas povoações, de tal forma em que, quando Fernando Magno procedia à concessão de forais nas zonas mais montanhosas do Norte, aparenta existir uma certa uniformidade relativamente ao roubo: estritamente proibido dentro das comunidades, mas permitido legalmente entre elas, sendo que o rei ficaria com um quinto do mesmo (TENTE, 2017 in CARVALHO et allii, 2017). Finalmente, a divisão provincial eclesiástica segue, de forma próxima, a divisão administrativa de Dioclesiano, no século IV, estando Valpaços sob a alçada da Dioceses de Braga, tal como atestas vários marcos no concelho (PEREIRA e MACHADO, 202O).

A materialidade da Alta Idade Média é mais complexa, sobretudo tendo em conta que temos um vazio de documentação para o território importante. Paralelamente, a construção não oficial e não eclesiástica na Idade Média dá primazia aos materiais perecíveis, como madeira e outros materiais vegetais. $\mathrm{O}$ mesmo se pode dizer de grande parte dos elementos do dia a dia, desde os instrumentos ao vestuário, fazendo com que muitos dados da vivências das populações deste território sejam extremamente difíceis de abordar. O primeiro documento conhecido para este período refere-se a uma doação (PARENTE, 2013: 69), em 109o, de um terreno em Rio Torto. Outros 
documentos deste género são conhecidos para o território. No entanto, os primeiros forais régios e outros documentos para o actual território datam já do período da nacionalidade $2^{4}$, tal como a maior parte da documentação mais antiga conhecida para o território em questão.

No entanto, sobreviveram alguns dados do período medieval de Valpaços. Um dos mais notórios são as sepulturas escavadas na rocha. De um total de 16 sepulturas deste género conhecidas no concelho, a maioria encontra-se nas zonas de eixos viários, tanto do iter XVII como da via medieval entre Murça e Vale de Telhas. Relativamente ao património religioso, podemos ainda referir a existência de alguns elementos, em igrejas recentes, que poderão ter sido re-aproveitados durante re-construções, de edifícios religiosos mais antigos, tal como sucede com a Igreja de Lampaça, onde são re-utilizados elementos romanos mas também medievais no edifício de construção recente.

Finalmente, no século XIII, em 1258, as inquirições de Afonso III (PARENTE, 2013: 535 a 537), referem 22 povoações no território actual de Valpaços, existindo todas ainda hoje em dia (Figura 5).

\section{UM PATRIMÓNIO MULTI-SECULAR MAS POUCO DISCUTIDO: OS LAGARES ESCAVADOS NA ROCHA}

Um pouco por toda a bacia mediterrânica, desde o Próximo Oriente (FRANKEL, 1998) até ao estreito de Gibraltar, são conhecidas estruturas escavadas na rocha, de morfologias muito distintas, associadas à produção de vinho (e, em muitos casos, de outros produtos, como mel, azeite, perfumes, etc).

Desde cedo que as estruturas de lagares escavados na rocha começam a ser estudadas no contexto peninsular e durante o último século, vários investigadores têm-se debruçado sobre o tema, em maior ou menos extensão $3^{5}$. Todavia, a dificuldade em datar e estudar as suas morfologias, a sua localização se en-

\footnotetext{
4. Aqui podemos citar o caso da doação de Argeriz, por Afonso Henriques, ao Mosteiro de Salzedas, em 1152 (FREITAS, 2001 e PARENTE; 2013).

5. Carlos Alberto Brochado de Almeida, António do Nascimento Sá Coixão, Catarina Tente, Adérito de Freitas, Yolanda de Peña Cervantes ou Alberto Reboreda são apenas alguns de uma longa lista de investigadores que trabalham ou trabalharam esta questão.
}

contrar muitas vezes em zonas de difícil acesso e este ser um tema difícil faz com que muitas vezes seja desanimador trabalhar este tema. Paralelamente, o facto de os lagares escavados na rocha levantarem, ainda hoje, tantas questões fazem com que este seja um tema extremamente interessante.

Um dos pontos mais importantes em análise são as razões que levaram à construção dos lagares escavados na rocha. Uma estrutura de tipo lagar necessita de uma zona de prensagem, ou calcatorium, e uma zona de recolha, ou lacus. No entanto, muitas estruturas possuem apenas uma zona de prensagem, sendo o resultado da mesma recolhido numa zona inferior, com uma peça móvel (Figura 6).

Analisando os lagares dispersos pelo território de Valpaços, encontramos um total de 120 estruturas, com um total de oito tipologias funcionais. Entre os indivíduos conhecidos, a maior parte concentra-se em zonas isoladas ainda hoje, sendo as teorias que nos parecem mais coerentes para a construção destes lagares a de que as estruturas serviriam para produzir vinho próximas de vinhas com acessos mais complexos, permitindo transportar o líquido diretamente para a sua zona de estágio, e, eventualmente, a fuga a taxas e dízimas a pagar pela produção de vinho, sobretudo a partir da Idade Média. Embora as duas teorias sejam concomitantes, elas poderão explicar a localização isolada das estruturas (Figura 7). Uma outra questão interessante é a do quando é que as estruturas são utilizadas. Embora ainda não tenha sido possível estabelecer um paralelo directo com Valpaços, sabemos que noutros territórios os lagares escavados na rocha são utilizados até há muito pouco tempo (PEREIRA, 2017). A sua longa diacronia funcional dificulta a resposta à questão. No entanto, em alguns casos, como sucede com a estrutura das Trigueiriças, Santa Valha, a grande quantidade de material romano na zona aponta para, pelo menos, um início funcional no período romano, ainda que apenas em algumas das estruturas. Ao mesmo tempo, uma leitura da localização destas estruturas, discriminadas em tipologias, em cartografia, faz com que seja percetível uma possível utilização e discriminação de territórios a partir de sítios arqueológicos conhecidos da prospeção.

No caso do sítio da Muradelha, em Fiães, por exemplo, a concentração de lagares de tipologia semelhante, sobretudo na zona a Sul do sítio, com uma ocupação eminentemente romana, poderá indicar a localização de vinhas nessa zona, exploradas pelo 
mesmo proprietário ou conjunto de proprietários. Neste caso, existem cinco lagares escavados na rocha, quatro de tipo $\mathrm{A}_{1}$, um de tipo $\mathrm{A}_{5}$ e um de tipo $\mathrm{B}$, todos num raio de 800 metros. Ao mesmo tempo, no caso dos lagares do Vale da Fenda e da Ribeira da Lança, existem sete lagares de tipo Ar e três de tipo B1, todos num raio inferior a 800 metros, em vários vales, a partir de uma mancha de material de cronologia romana previamente desconhecida (PEREIRA e MACHADO, 2020), sendo que em três dos lagares foi identificado material de superfície de cronologia romana.

Ao longo do trabalho de relocalização e prospecção que foi realizado em Valpaços, foi possível, tendo em conta que foi analisado o território como um todo, compreender melhor tanto a organização das estruturas de lagares tal como encetar uma possível datação relativa dos mesmos.

\section{VALPAÇOS E A SUA CARTA ARQUEOLÓGICA}

Tal como observamos anteriormente, a produção de uma carta arqueológica é essencial para a organização das dinâmicas territoriais e administrativas de um município. Seja a partir da questão da proteção do património arqueológico, seja através de uma melhor estruturação do Plano Diretor Municipal, um elemento deste género permite ainda uma melhor leitura do território em questão ao longo uma cronologia ampla.

Ao longo da preparação desta carta arqueológica foi necessário contactar, para além das populações locais e juntas de freguesias, uma série de museus e cidadãos externos ao concelho, depositários de materiais arqueológicos provenientes de Valpaços. Foram ainda consultadas centenas de referências bibliográficas referentes ao concelho e ao território em questão.

O trabalho foi dividido em duas fases principais: a prospeção direccionada, sobretudo nos sítios que eram já conhecidos através da bibliografia e da base de dados do Endovélico; e a prospeção intensiva, realizada pontualmente em zonas com um maior potencial (Figura 8).

Foram inventariados um total de 344 sítios arqueológicos, desde a Pré-História à Idade Média, tendo sido propostas as classificações de onze sítios ou conjuntos mais emblemáticos ao município. Ao longo do trabalho foram confirmadas as ocorrências patrimoniais no território, o seu estado de conservação e dispersão, se consistissem em manchas de superfície, e foram realizados registos, tanto fotográficos como ortofotográficos, de estruturas e elementos que, devido a diversos fatores, poderiam estar em risco.

No final do trabalho será realizada uma apresentação pública de resultados e será produzida uma exposição itinerante sobre a carta arqueológica, ambas previstas para o final do ano corrente, e, durante os meses seguintes à elaboração deste artigo, serão realizadas sondagens de controlo em alguns sítios do concelho, de forma a tentar obter sequências estratigráficas seguras,, nomeadamente no Santuário de Argeriz e no Castro de Santa Valha (Figura 9).

Finalmente, o trabalho de uma carta arqueológica nunca pode ser considerado terminado. Novos sítios irão certamente aparecer no decurso dos próximos anos ou meses. Poderão ser iniciados projetos de investigação que abranjam o território de Valpaços e que, certamente, trarão surpresas e novidades para a história do concelho e do território em que se insere.

\section{BIBLIOGRAFIA}

ALARCÃO, Jorge de (1988) - Roman Portugal. Vol. I. Warminster: Aris \& Phillips.

ALVES, Francisco Manuel (1938) - Memórias arqueológico-históricas do distrito de Bragança: arqueologia, etnografia e arte. Porto: Emp. Guedes, Vol. 10.

BARRADAS, Lereno Antunes (1956) - Vias romanas das regiões de Chaves e Bragança.In: Revista de Guimarães. Guimarães. 66: 12, p.159-240.

BARROCA, Mário (1987) - Necrópoles e Sepulturas Medievais de Entre-Douro e Minho (séculos Va XV). Policopiado.

BURGESS, Richard (1993) - The Chronicle of Hydatius and the Consularia Constantinopolitana. Oxford: Clarendon Press.

CARVALHO, Pedro, GOMES, Luís Filipe Coutinho e MARQUES, João Nuno (coord.) (2017) - Estudo histórico e etnológico do vale do Tua (Concelhos de Alijó, Carrazeda de Ansiães, Mirandela, Murça e Vila Flor), EDP/Edições Afrontamento.

CASTRO, Luís de Albuquerque e CORDEIRO, L. (1963) Um "fornax "lusoromano. In Estudos, Notas e Trabalhos do Serviço do Fomento Mineiro. Lisboa. 16: 12, pp. 117-128.

FONTE, João e CARDOSO, Ismael (2005) - O Castelo de Monforte de Rio Livre. In Al-madan. IIa Série. № 13 .

FONTE, João e COSTA-GARCIA, José Manuel (2016) - Alto da Cerca (Valpaços, Portugal): Um assentamento militar ro- 
mano na Serra da Padrela e sua relação com o distrito mineiro de Tresminas. Estudos do Quaternário.№ 14, pp. 39-56.

FRANKEL, Rafael (1998) - Wine and Oil Production in Antiquity in Israel and Other Mediterranean Countries. Jsot/ Asor Monographs, $\mathrm{n}^{\circ} 10$.

FREITAS, Adérito Medeiros de (2001) - Carta Arqueológica de Valpaços. Valpaços: Câmara Municipal de Valpaços.

FREITAS, Adérito Medeiros de (2010) - Lagares cavados nas rochas. Valpaços: Câmara Municipal de Valpaços.

FREITAS, Adérito Medeiros de (2011) - Corpus dos Petróglifos de Valpaços. Valpaços: Câmara Municipal de Valpaços.

JORGE, Vitor Oliveira (1983-1984) - Megalitismo no Norte de Portugal. Um novo balanço. Portugália. Nova Série. Vol.. Porto; Faculdade de Letras da Universidade do Porto

LEMOS, Francisco Sande (1993) - Povoamento Romano de Trás-os-Montes Oriental. Braga: Universidade do Minho, 6 Vols. Policopiado.

LOPO, Joaquim de Castro (1954) - O Concelho de Valpaços. Lourenço Marques: Edição do Autor.

NETO, Albertino Chan Rodrigues e CHAVES, Carlos Alberto Roque Neto (2011) - Relatório sobre o Descritor Património Arqueológico, Arquitetónico e Etnológico do Estudo de Impacte Ambiental dos Aproveitamentos Hidroeléctricos dos rios Calvo e Rabaçal (Mirandela e Valpaços). Policopiado.

PARENTE, João (2013) - Idade Média no Distrito de Vila Real - Documentos desde o ano 569 ao ano 1278. Tomo I. Âncora editores.

PEÑA CERVANTES, Yolanda (2019) - Los lagares rupestres de la Península Ibérica: sistemas de estrujado y problemática cronológica. In ArkeoGazte: Revista de arqueología Arkelogia aldizkaria, №. 9 (Ejemplar dedicado a: Arqueología y trabajo), pp. 83-99.

PEREIRA, Luís e LOPES, Alexandra Justo (2007) - Relocalização, identificação e inspecção de sítios pela Extensão do IPA - Macedo de Cavaleiros.

PEREIRA, Pedro (2017) - O Vinho na Lusitânia. CITCEM/ Afrontamento.

PEREIRA, Pedro, VANZELLER, José e NEVES, Joana (2003) - Levantamento e análise das gravuras de Nossa Senhora da Ribeira, Lebução. Trabalho apresentado na cadeira de Trabalhos Práticos de Arqueologia II. FLUP (policopiado).

PEREIRA, Pedro e MACHADO, Maria de Fátima (2020) Carta Arqueológica de Valpaços. Inédito.

RIBEIRO, Joana (2007) - Entre a Gravura e a Escultura: A Estação Rupestre de Lampaça no contexto da arte de ar livre da região. Trabalho apresentado na cadeira de Seminário de Projecto. FLUP. (policopiado).

RODRÍGUEZ COLMENERO, António, AIRES, Firmino e ALCORTA, Enrique (1997) - Aqvae Flaviae I. Fontes Epi- gráficas da Gallaecia Meridional Interior. Chaves: Câmara Municipal de Chaves.

SANCHES, Maria de Jesus (1994) - Megalitismo na bacia de Mirandela. In Actas do Seminário "O Megalitismo no Centro de Portugal». Viseu: Centro de Estudos Préhistóricos da Beira Alta, (Estudos PréHistóricos, 2), pp. 249-284.

SANCHES, Maria de Jesus (1997) - Pré-História recente de Trás-os-Montes e Alto Douro. O abrigo do Buraco da Pala (Mirandela) no contexto regional). In Textos. Porto: Sociedade Portuguesa de Antropologia e Etnologia, (Textos, 1), 2 Vols.

SILVA, Armando Coelho Ferreira da (1986) - A Cultura Castreja no Noroeste de Portugal. Paços de Ferreira: Museu Arqueológico da Citânia de Sanfins e Câmara Municipal de Paços de Ferreira.

SILVA, Pedro Miguel Reis (2016) - Povoamento Proto-Histórico do alto Tâmega: as mudanças do I milénio a.C. e a resistência do substrato indígena. Porto: Faculdade de Letras da Universidade do Porto (policopiado).

TEIXEIRA, Ricardo Jorge Coelho Marques Abrantes (1996) - De Aquae Flaviae a Chaves. Povoamento e organização do território entre a Antiguidade e a Idade Média. Porto: Faculdade de Letras da Universidade do Porto (policopiado).

TEIXEIRA, Ricardo Pinheiro (2015) - A Evolução do Povoado e Castelo de Monforte de Rio Livre na Idade Média. Porto: Faculdade de Letras da Universidade do Porto.

VIEIRA, Alexandra (2015) - Contributo para o estudo dos vestígios arqueológicos - do VI ao I milénio a.C.. Paisagens e memórias na bacia hidrográfica do Douro. Tese apresentada à Faculdade de Letras da Universidade do Porto para obtenção de grau de Doutor em Arqueologia. Policopiada. 


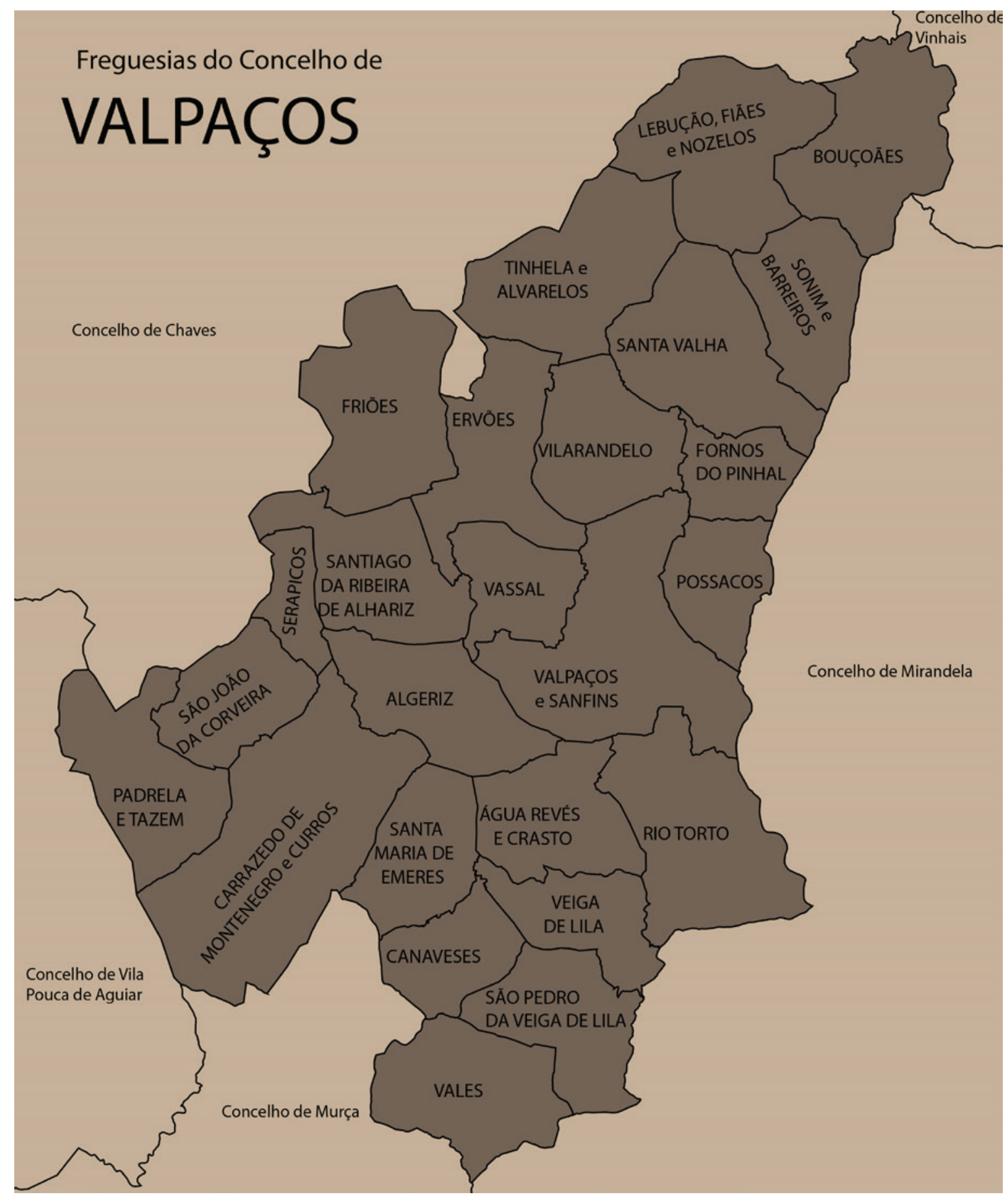

Figura 1 - Mapa do Concelho de Valpaços.(adaptado pelos autores a partir do mapa da Direcção-Geral do Território, Carta Administrativa Oficial de Portugal (CAOP), versão 2013). 


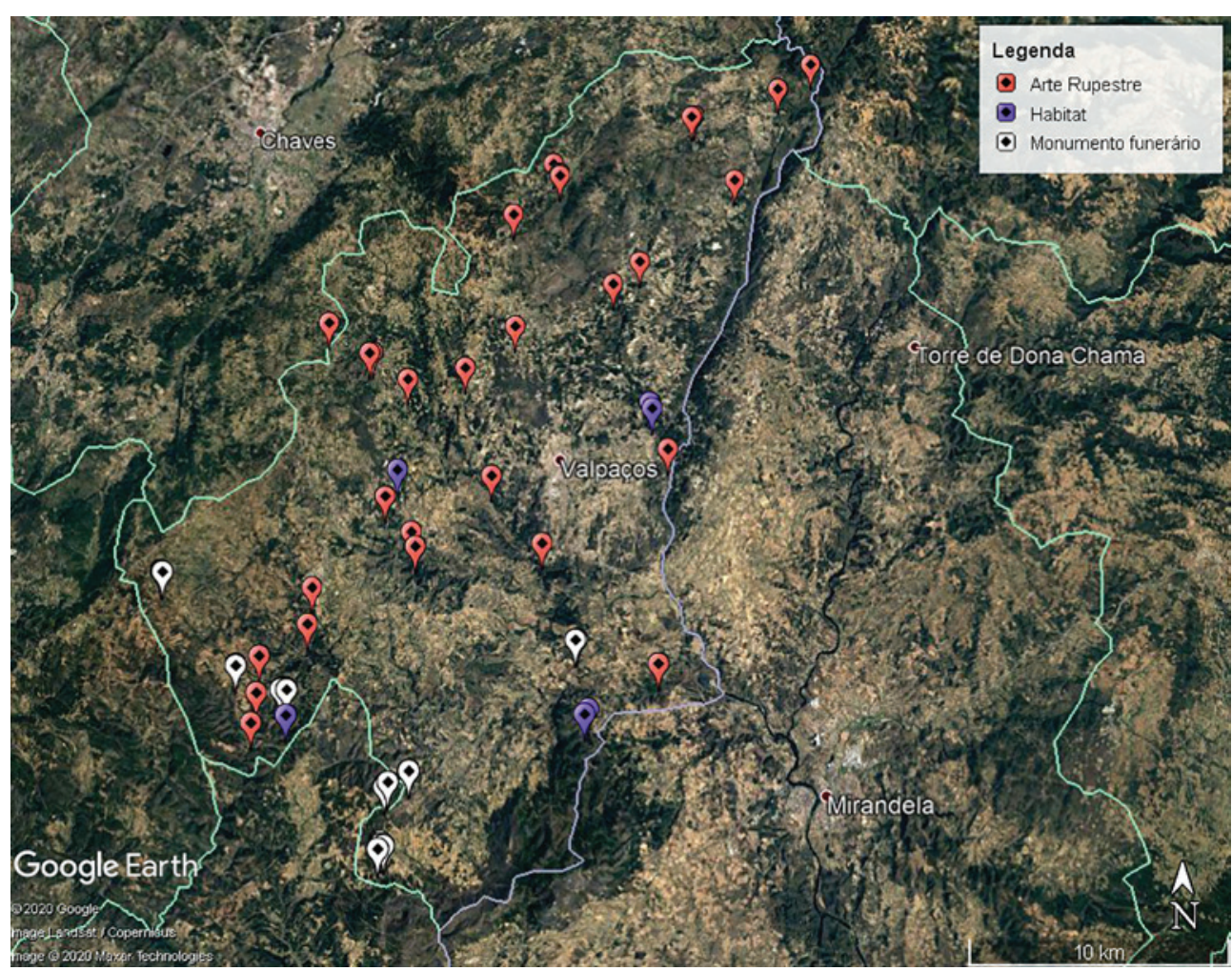

Figura 2-Mapa com a localização dos vários tipos de sítios com ocupação durante a Pré-História no Concelho de Valpaços.

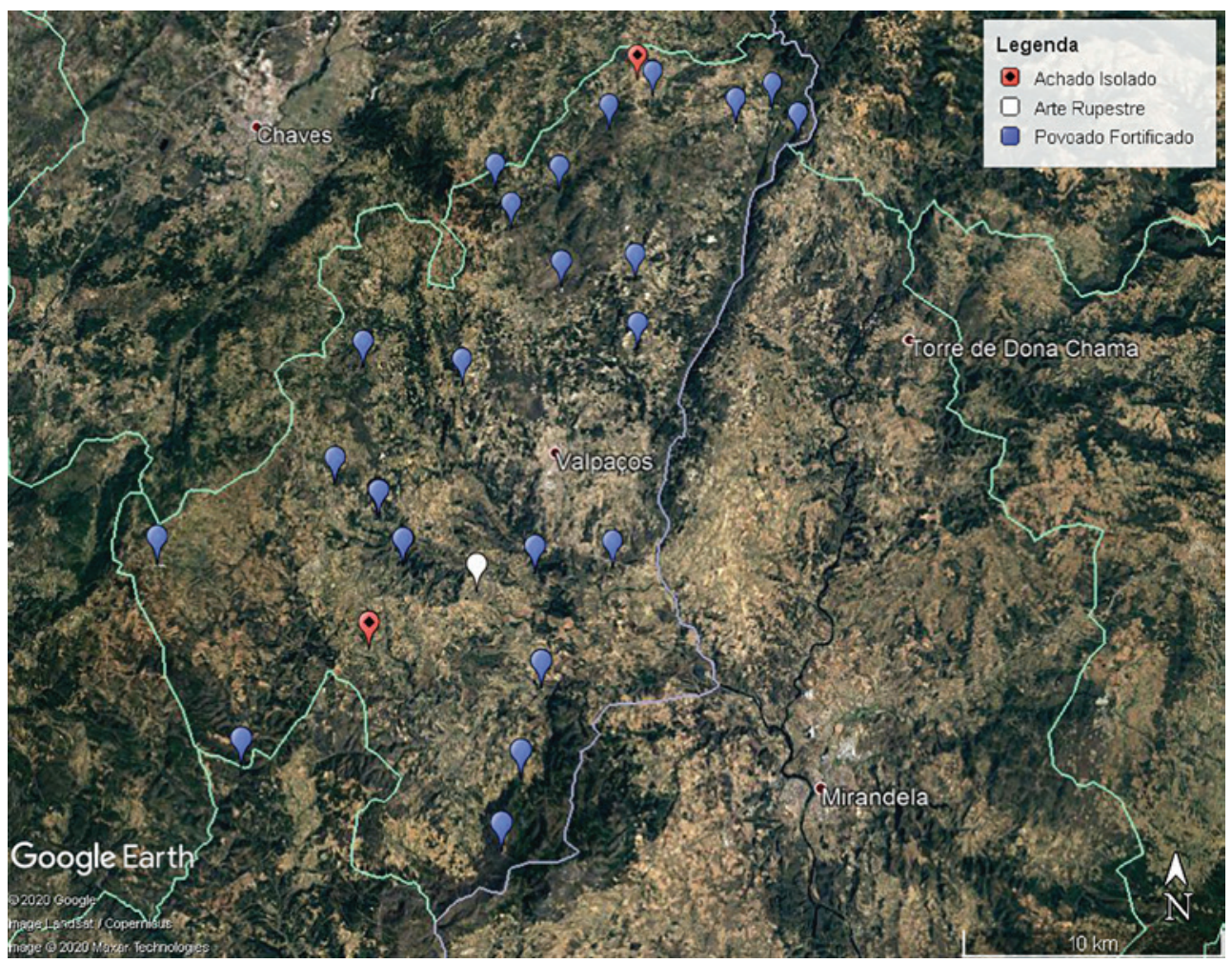

Figura 3 - Mapa com a localização dos vários tipos de sítios com ocupação durante a Proto-História no Concelho de Valpaços. 


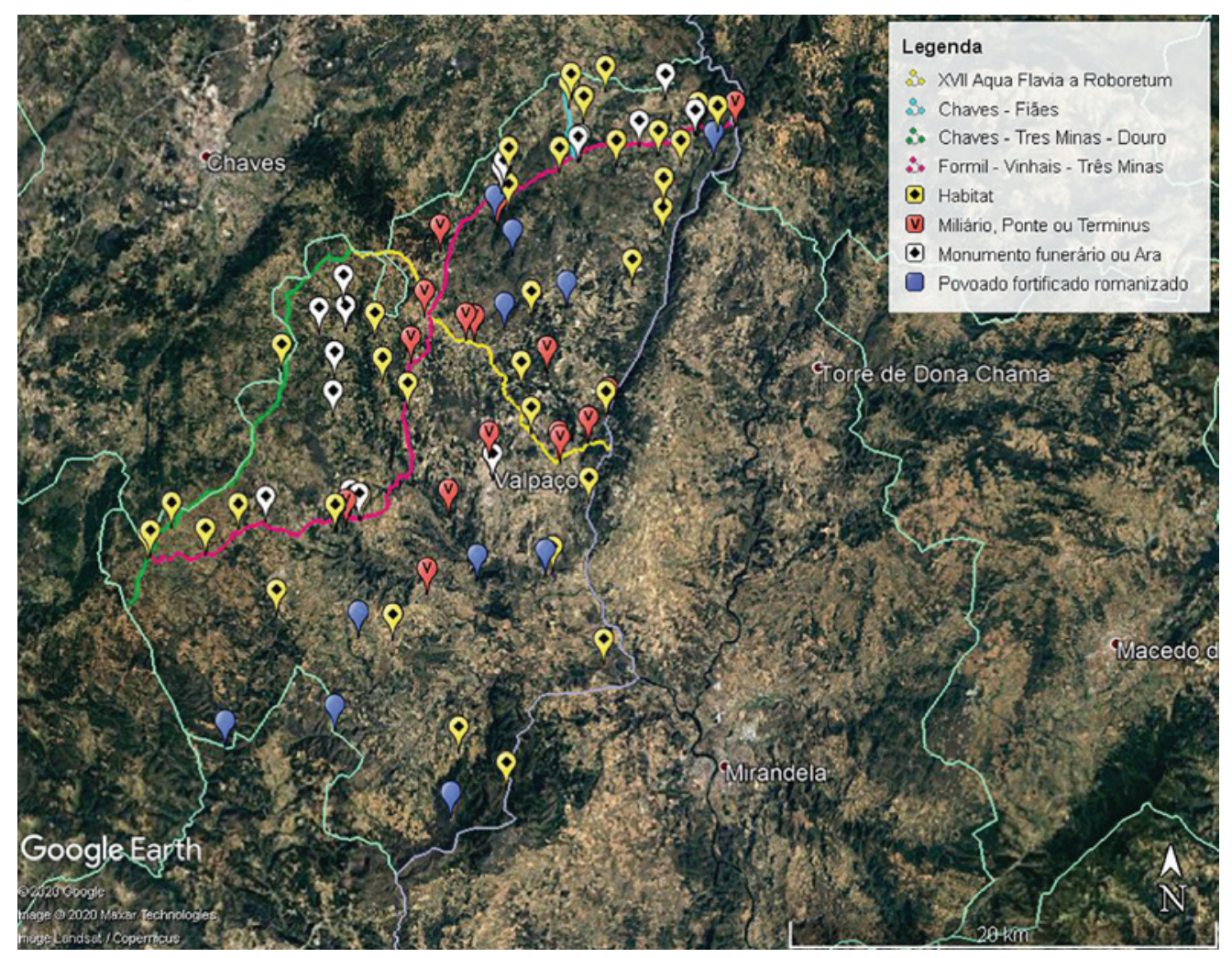

Figura 4-Mapa com a localização dos vários tipos de sítios com ocupação durante o período romano e vias conhecidas no Concelho de Valpaços.

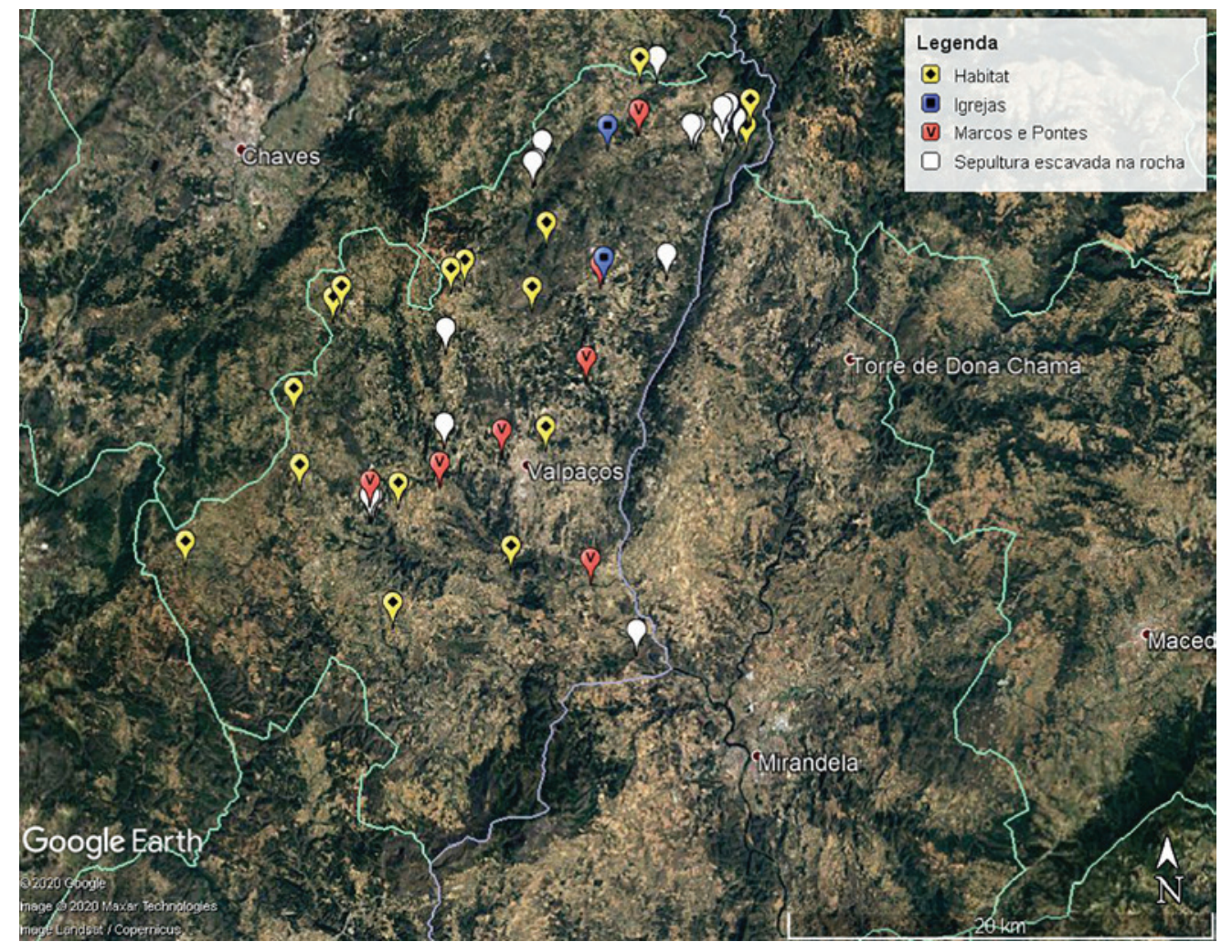

Figura 5-Mapa com a localização dos vários tipos de sítios com ocupação durante o período medieval e no Concelho de Valpaços. 


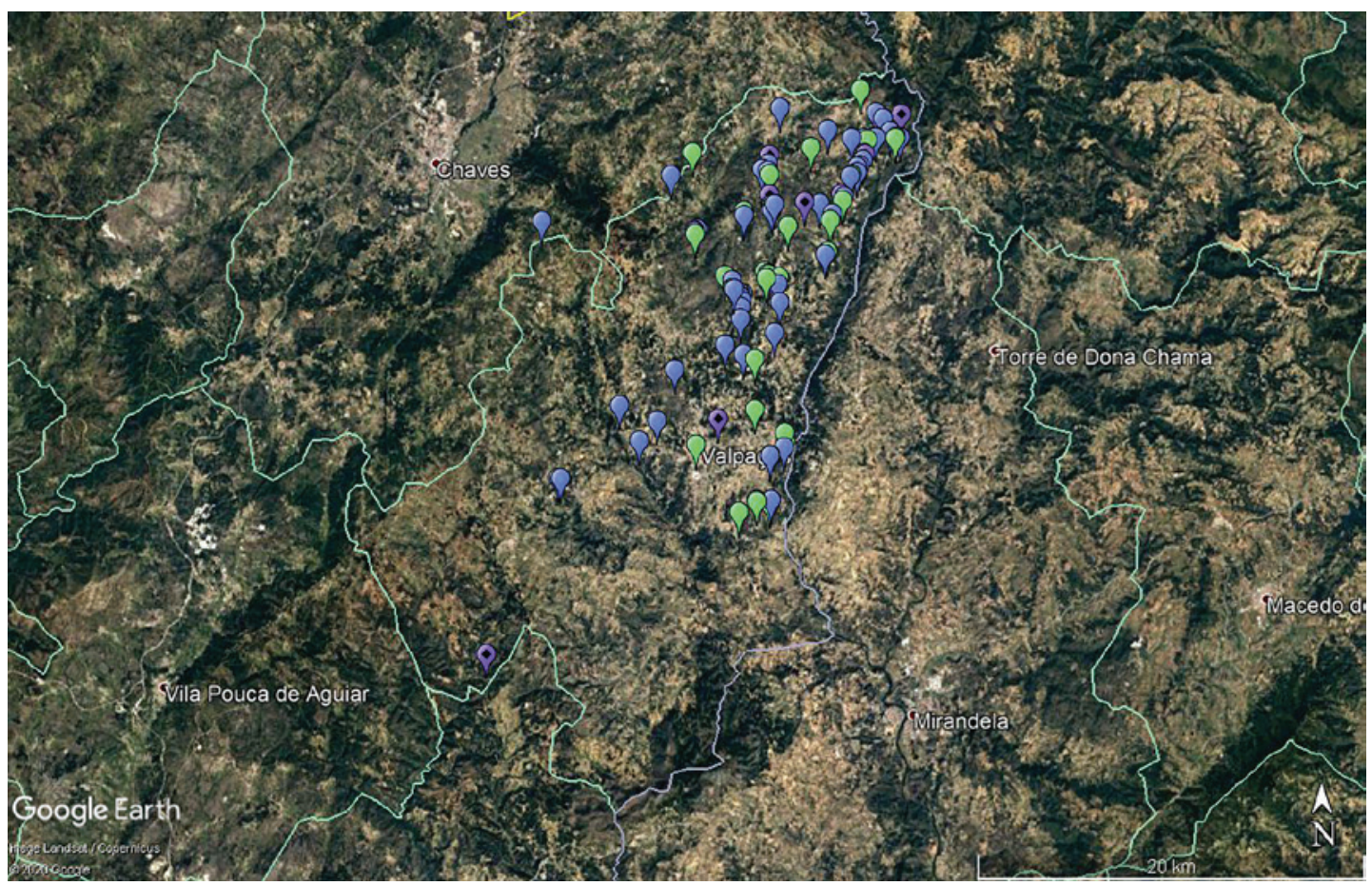

Figura 6 - Dispersão e localização dos lagares escavados na rocha no concelho de Valpaços.

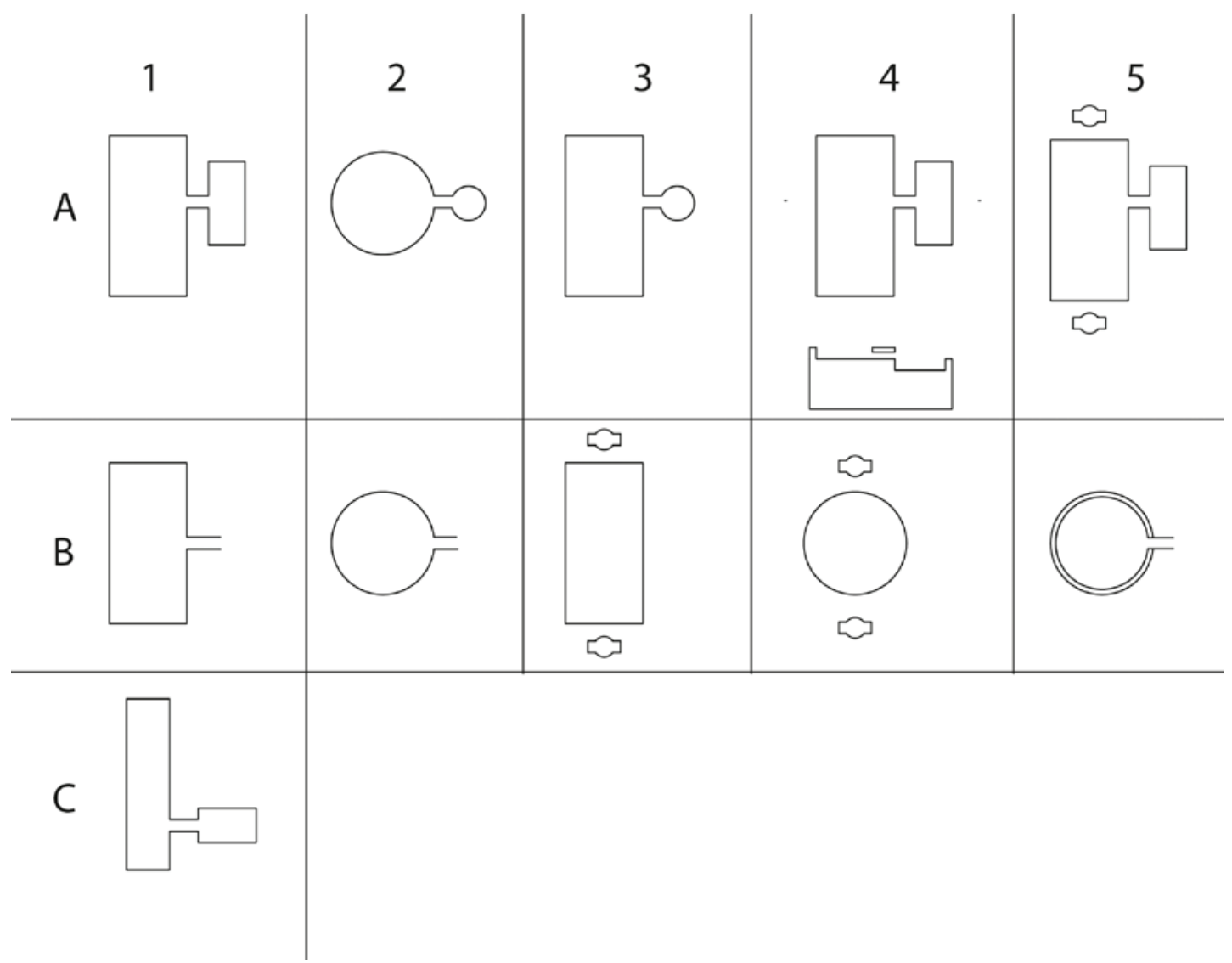

Figura 7 - Tipologias de plantas utilizadas para os lagares rupestres em Valpaços. 


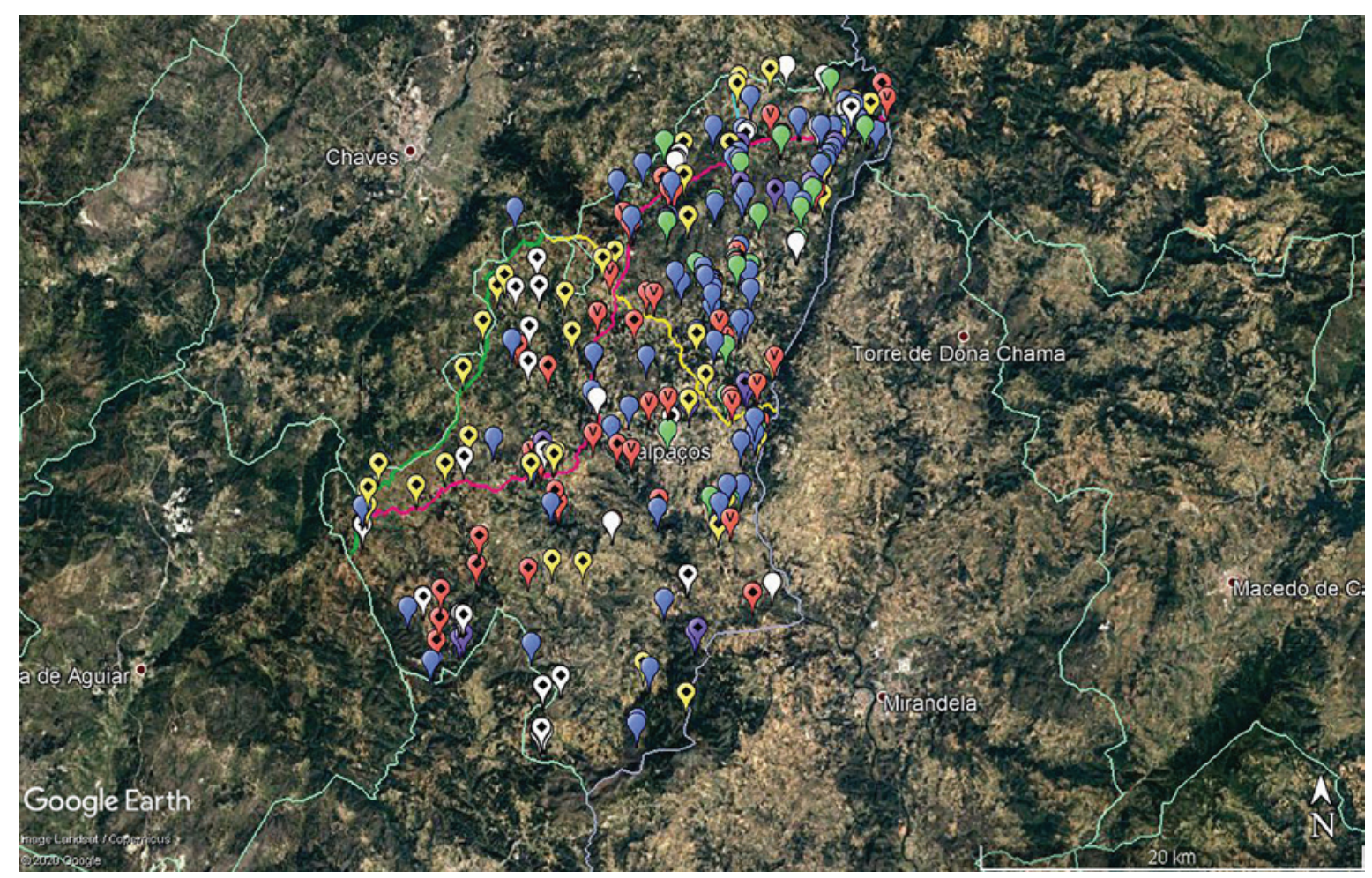

Figura 8 - Ortofotomapa com a localização de todos os sítios arqueológicos conhecidos no concelho de Valpaços.

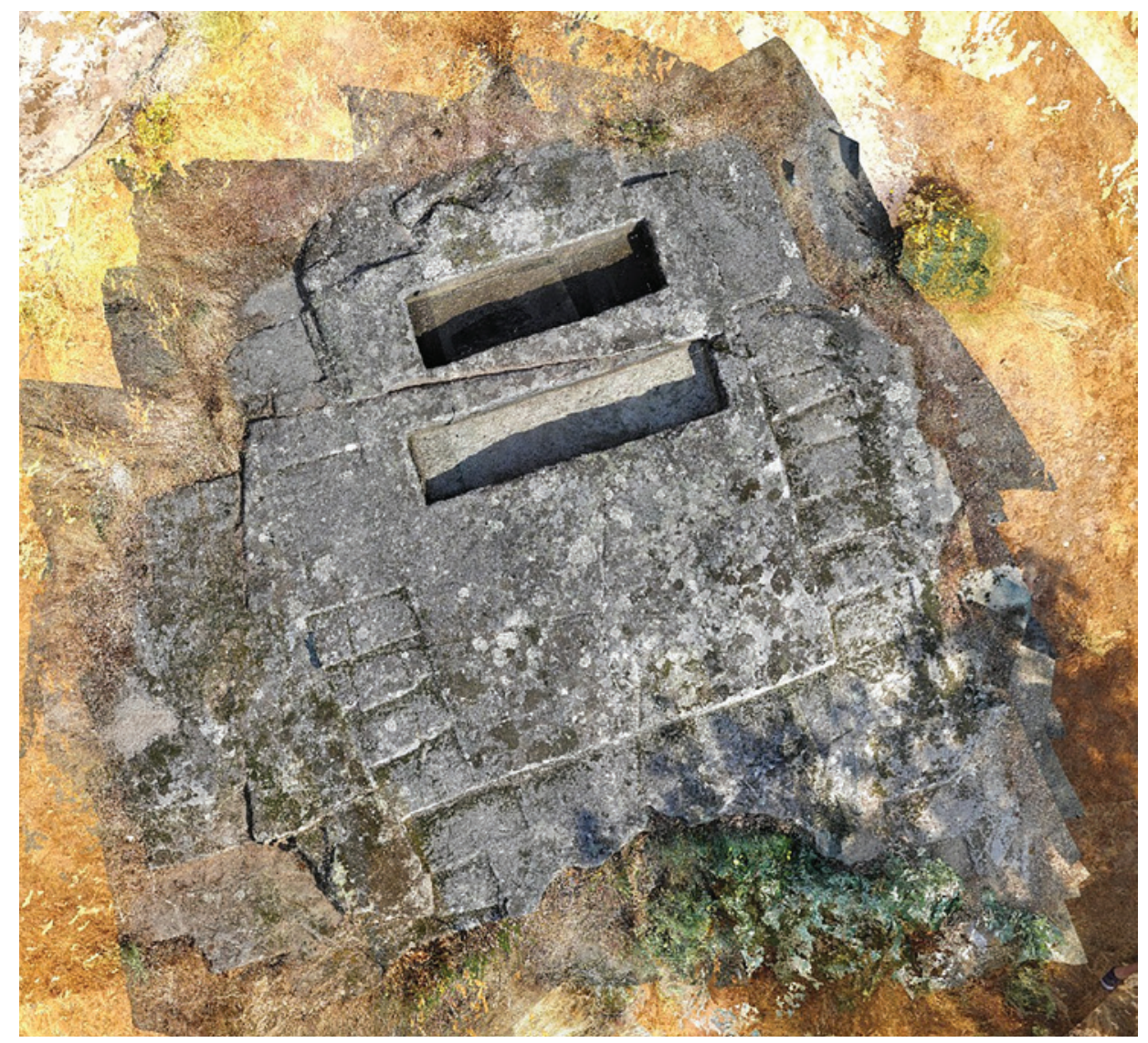

Figura 9 - Santuário de Argeriz. Ortofotografia prévia à intervenção no sítio. 



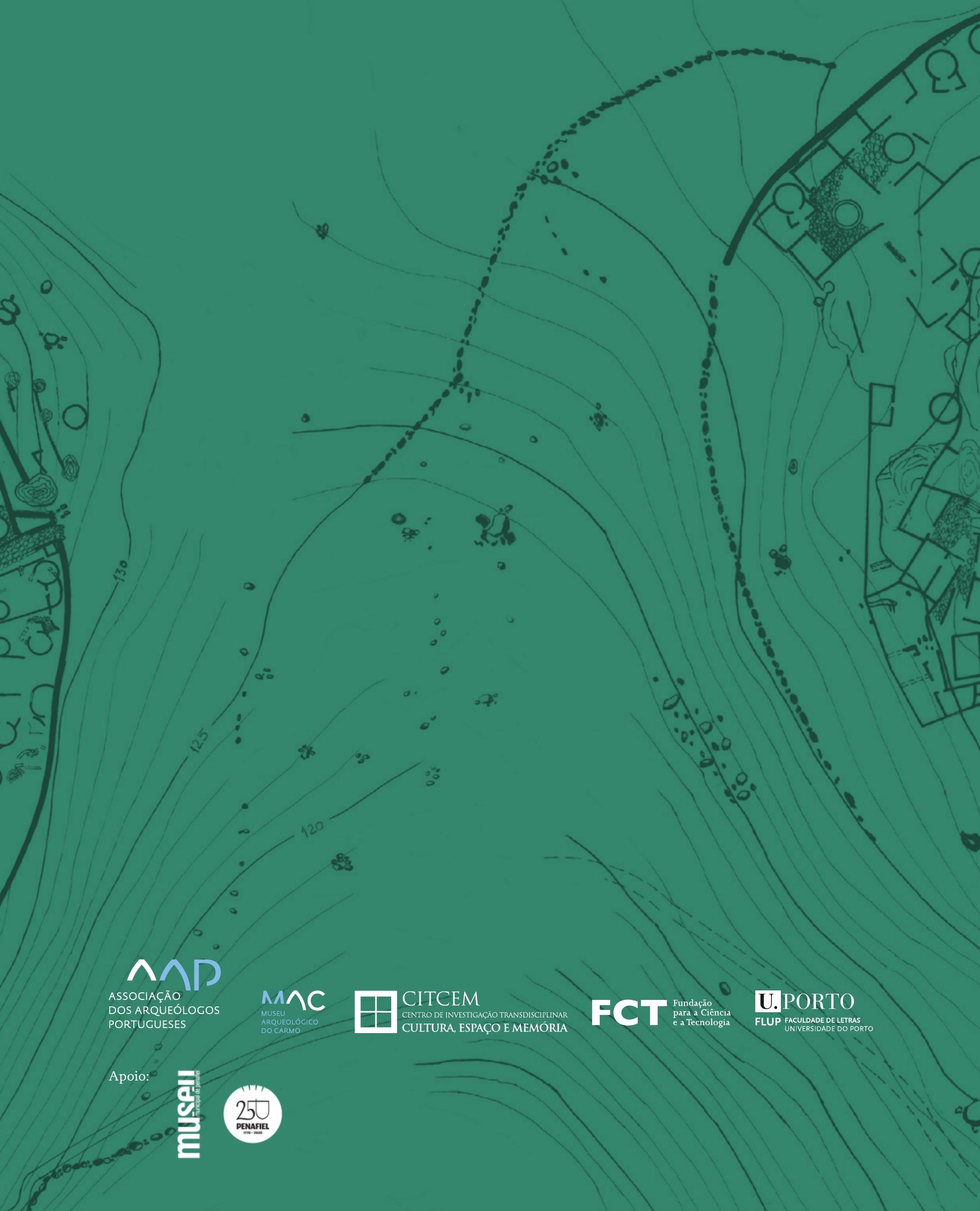

